\title{
What do we know about Tietze's syndrome?
}

\author{
Wojciech Rokicki, Marek Rokicki, Mateusz Rydel \\ Department and Clinic of Thoracic Surgery in Zabrze, Medical University of Silesia in Katowice, Poland
}

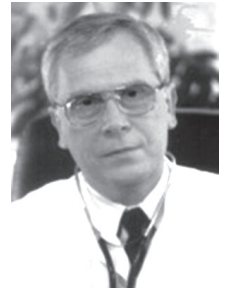

Kardiochirurgia i Torakochirurgia Polska 2018; 15 (3): 180-182

\begin{abstract}
Tietze's syndrome is a benign, self-limiting arthropathy, without purulent character. The disease most often involves articulations: sternocostal, sternoclavicular, or costochondral joints. The characteristic symptoms are tenderness, pain and edema involving one of the aforementioned joints on one side. Diagnosis of Tietze's syndrome is based on physical examination (increase of palpation tenderness in the affected joint), laboratory tests (increase of inflammatory parameters) and imaging studies (USG, MRI). Differential diagnosis of Tietze's syndrome is based on exclusion of costal cartilage inflammation, coronary syndrome and inflammatory changes in the lung and pleura. Most commonly the treatment is conservative, in resistant cases surgical.
\end{abstract}

Key words: Tietze's syndrome, arthropathy, sternocostal articulation.

Tietze's syndrome is defined as non-purulent, mildly selflimiting arthropathy, characterized by tenderness, pain and edema (70-80\%), involving articulations: sternocostal and/ or sternoclavicular on one side, with no other symptoms [1-3]. This clinically individual disease unit is often confused with other painful conditions within the thoracic skeletal structures such as costochondritis, which is not accompanied by tissue swelling inside the sternocostal joint $[2,4,5]$.

This syndrome of clinical symptoms was first described in 1921 by the German professor of surgery Alexander Tietze, who was an assistant to Jan Mikulicz-Radecki [6]. The etiopathogenesis of Tietze's syndrome remains poorly understood. It is believed that most commonly it is caused by micro-injuries and/or infection of the airways [7].

The symptoms of Tietze's syndrome are not characteristic and include point pain within the anterior half of the chest wall radiating to the shoulder and arm, exacerbated by sneezing, deep breathing and torsional movements of the torso. During the exacerbation of symptoms of Tietze's syndrome, additionally there was observed increased palpation tenderness within the occupied sternocostal joint, leukocyto-

\section{Streszczenie}

Zespół Tietzego jest łagodną, samoograniczającą się artropatią, która nie ma ropnego charakteru. Choroba obejmuje najczęściej stawy mostkowo-żebrowe, mostkowo-obojczykowe lub połączenia części chrzęstnej i kostnej żeber. Charakterystycznymi objawami są: tkliwość uciskowa, ból i obrzęk obejmujące po jednej stronie któryś z wyżej wymienionych stawów. Diagnostyka zespołu Tietzego opiera się na badaniu fizykalnym (wzrost tkliwości palpacyjnej w obrębie zajętego stawu), badaniach laboratoryjnych (zwiększenie parametrów stanu zapalnego) i badaniach obrazowych (USG, MRI). W diagnostyce różnicowej zespołu Tietzego bierze się pod uwagę zapalenie chrząstek żebrowych, zespoły wieńcowe oraz zmiany zapalne w obrębie płuc i opłucnej. Najczęściej stosuje się zachowawcze metody leczenia, a w przypadkach opornych - metody zabiegowe.

Słowa kluczowe: zespół Tietzego, artropatia, staw mostkowo-żebrowy.

sis, C-reactive protein (CRP), erythrocyte sedimentation rate (ESR) and body temperature to $38^{\circ} \mathrm{C}$ [8]. Tietze's syndrome may be additionally accompanied by dermatological symptoms such as palm and plantar pustulosis and psoriasis [7].

In physical examination, in over $70 \%$ of patients one side of the thorax is swollen and there is noted palpable tenderness of the sternocostal joint, most often the second and/or third rib. It is recommended that during the physical examination, with a single finger, one should apply gentle pressure to the front, lateral and posterior chest wall in order to accurately locate the discomfort $[9,10]$.

Diagnosis of Tietze's syndrome is based on basic clinical trials that exclude other diseases, in particular costal cartilage inflammation (costochondritis), coronary syndromes and inflammatory changes in the lungs and pleura [11]. Costochondritis, also known as sternocostal syndrome, chondrodynia or front chest wall syndrome, is often confused with Tietze's syndrome. Significant differences between these two disease entities are presented in Table I [12].

Tietze's syndrome is a relatively rare disease and it is advisable to perform additional imaging tests to correct-

Address for correspondence: Mateusz Rydel MD, Department and Clinic of Thoracic Surgery, Medical University of Silesia, 13-15 3-go Maja St, 41-800 Zabrze, Poland, phone: +48 506039 825, +48 506039 825, fax: +48 506039 825, e-mail: mateusz.rydel@wp.pl

Received: 5.02.2018, accepted: 3.04.2018. 
Table I. Comparison between costochondritis and Tietze's syndrome

\begin{tabular}{|c|c|c|}
\hline Characteristics & Costochondritis & Tietze's syndrome \\
\hline Signs of inflammation & Absent & Present \\
\hline Swelling & Absent & Presence or absence indicates severity of problem \\
\hline Joints affected & $\begin{array}{l}\text { Multiple and unilateral }>90 \% \text {. Usually second to } \\
\text { fifth costochondral junctions involved }\end{array}$ & $\begin{array}{l}\text { Usually single and unilateral. Usually second and } \\
\text { third costochondral junctions involved }\end{array}$ \\
\hline Prevalence & Relatively common & Uncommon \\
\hline Age group affected & All age groups, including adolescents and elderly & Common in younger age group \\
\hline Nature of pain & Aching, sharp, pressure like & $\begin{array}{l}\text { Aching, sharp, stabbing initially, later persists as } \\
\text { dull aching }\end{array}$ \\
\hline Onset of pain & $\begin{array}{l}\text { Repetitive physical activity provokes pain, rarely } \\
\text { occurs at rest }\end{array}$ & $\begin{array}{l}\text { New vigorous physical activity such as excessive } \\
\text { cough or vomiting, chest impact }\end{array}$ \\
\hline Aggravation of pain & $\begin{array}{l}\text { Movements of upper body, deep breathing, } \\
\text { exertional activities }\end{array}$ & Movements \\
\hline Association with other conditions & Seronegative arthropathies, anginal pain & No known association \\
\hline Diagnosis & $\begin{array}{l}\text { Crowing rooster maneuver and other physical } \\
\text { examination findings }\end{array}$ & $\begin{array}{l}\text { Physical examination, exclude rheumatoid } \\
\text { arthritis, pyogenic arthritis }\end{array}$ \\
\hline Imaging studies & $\begin{array}{l}\text { Chest radiograph, computed tomography scan, } \\
\text { or nuclear bone scan to rule out infections or } \\
\text { neoplasms if clinically suspected }\end{array}$ & $\begin{array}{l}\text { Bone scintigraphy and ultrasonography can be } \\
\text { used for screening for other conditions }\end{array}$ \\
\hline Treatment & $\begin{array}{l}\text { Reassurance, pain control, nonsteroidal } \\
\text { antiinflammatory drugs, application of local } \\
\text { heat and ice compresses, manual therapy } \\
\text { with stretching exercises. Corticosteroid or } \\
\text { sulfasalazine injections in refractory patients }\end{array}$ & $\begin{array}{l}\text { Reassurance, pain control with nonsteroidal } \\
\text { antiinflammatory drugs, and application of local } \\
\text { heat. Corticosteroid and lidocaine injections to the } \\
\text { cartilage, or intercostal nerve block in refractory } \\
\text { patients }\end{array}$ \\
\hline
\end{tabular}

ly diagnose it. Ultrasound imaging is the most common method, which shows swelling of soft tissues at the site of the ongoing inflammatory process. In turn, the nuclear magnetic resonance (NMR) very accurately shows inflammatory changes in the surrounding fat tissue along with bone marrow edema causing compression and close adherence of the joint surfaces forming the articulation. There are no destructive changes in cartilage and bone. Another recommended method is skeletal scintigraphy using technetium-99 or radioactive gallium. The above studies allow for differentiation between Tietze's syndrome and costochondritis in which significant inflammatory changes within the rib structure are evident [13-15].

So far there are no clinical trials in the literature discussing the methods of treatment of Tietze's syndrome. Particularly, conservative methods of treatment are used, which include pain management using analgesics and nonsteroidal anti-inflammatory drugs. In rare cases resistant to the above-mentioned pharmacological methods, the site of the pain can be injected with a solution of lignocaine in combination with a steroid. Warming wraps for the painful place are also recommended. In individual cases, resection of the cartilage has been described. A few-week limitation of physical activity is also recommended. Treatment with the aforementioned methods should be continued until the pain is completely resolved. On average, the symptoms disappear after 1-2 weeks of such treatment. In rare cases, the pain may remain chronic $[3,12,13]$.
Table II. Costochondritis and Tietze's syndrome summary

\begin{tabular}{|c|c|c|}
\hline Feature & Costochondritis & Tietze's syndrome \\
\hline Prevalence & More common & Rare \\
\hline Age & Older than 40 years & Younger than 40 years \\
\hline $\begin{array}{l}\text { Number of sites } \\
\text { affected }\end{array}$ & $\begin{array}{l}\text { More than one (in } 90 \% \\
\text { percent of patients) }\end{array}$ & $\begin{array}{l}\text { One (in } 70 \% \\
\text { of patients) }\end{array}$ \\
\hline $\begin{array}{l}\text { Costochondral } \\
\text { junctions most } \\
\text { commonly affected }\end{array}$ & Second to fifth & Second and third \\
\hline Local swelling & Absent & Present \\
\hline
\end{tabular}

In conclusion, it should be emphasized that Tietze's syndrome is a relatively rare disorder most commonly seen in young people (up to 35 years of age). Typically, in about $70 \%$ of cases it appears only on one side of the chest and most often affects the attachment of 2 and/or 3 ribs to the sternum. In Tietze's syndrome painful swelling of this area is always found, which allows for the differentiation of this disease entity from costochondritis. The most frequently reported differences are presented in Table II [16].

In patients over 35 years of age reporting chest pain, a history of coronary heart disease and/or cardiorespiratory disease prior to diagnosing Tietze's syndrome, it is standard to perform ECG and chest X-ray to exclude them [16].

\section{Disclosure}

The authors report no conflict of interest. 


\section{References}

1. Aeschlimann A, Kahn M. TS: a critical review. Clin Exp Rheumatol 1990; 8: 407-412.

2. Fam A, Smuythe H. Musculoskeletal chest wall pain. Can Med Assoc J 1985; 133: 379-389.

3. Kamel M, Kotob H. Ultrasonographic assessment of local steroid injection in Tietze's syndrome. Br J Rheumatol 1997; 36: 547-550.

4. Peyton F. Unexpected frequency of idiopathic costochondral pain. Obstet Gynecol 1983; 62: 605-608.

5. Stochkendahl MJ, Christensen HW. Chest pain in focal musculoskeletal disorders. Med Clin N Am 2010; 94: 259-273.

6. Tietze A. Űber eine eigenartige Häufung von Fällen mit Dystrophie der Rippenknorpel. Berliner klinische Wochenschrift 1921; 58: 829-831.

7. Jurik AG, Graudal H. Sternocostal joint swelling - clinical Tietze's syndrome. Report of sixteen cases and review of the literature. Scand J Rheumatol 1988; 17: 33-42.

8. Karabudak O, Nalnant S, Ulusoy RE, Dogan B, Harmanmyeri Y. Generalized nonspecific postular lesions in Tietze's syndrome. J Clin Rheumatol 2007; 13: 300-330.
9. Wiese CM, Sembie EL, Dalton CB. Musculoskeletal chest wall syndromes in patients with noncardiac chest pain: a study of 100 patients. Arch Phys Med Rehabil 1992; 73: 147-149.

10. Costochondritis. Stedman's Online Medical Dictionary. htpp//www.sted mans.com/section.cfm/45. Accessed April 15.2009.

11. Cayley WE Jr. Diagnosis the cause of chest pain. Am Fam Physician 2005; 72: 2012-2021

12. Ayloo A, Cvengros T, Marella S. Evaluation and treatment of musculoskeletal chest pain. Prim Care Clin Office Pract 2013; 40: 863-887.

13. How J, Voiz G, Doe S, Heycock C, Hamilton J, Kelly C. The causes of musculoskeletal chest pain in patients admitted to hospital with suspected myocardial infarction. Eur J Intern Med 2005; 16: 432-436.

14. Mendelson G, Mendelson H, Horowitz SF, Goldfarb CL, Zumoff B. Can (99m) technetum methylene diphosphate bone scars objectively document costochondritis? Chest 1997; 111: 1600-1602.

15. Ikehira H, Kinjo M, Nagase $\mathrm{Y}$, Aoki T, Ito H. Acute pain-costochondritis demonstrated by galium scintigraphy. Br J Radiol 199; 72: 210-285.

16. Proulx AM, Zryd TW. Costochondritis: diagnosis and treratment. Am Fam Phys 2009; 80: 617-620. 